Erratum

\title{
Erratum: Tröster, M.F.; Sauer, J. IoFarm in Field Test: Does a Cost-Optimal Choice of Fertilization Influence Yield, Protein Content, and Market Performance in Crop Production? Agriculture 2021, 11, 571
}

\section{Agriculture Editorial Office}

check for updates

Citation: Agriculture Editorial Office. Erratum: Tröster, M.F.; Sauer, J

IoFarm in Field Test: Does a

Cost-Optimal Choice of Fertilization Influence Yield, Protein Content, and Market Performance in Crop Production? Agriculture 2021, 11, 571. Agriculture 2021, 11, 709. https:// doi.org/10.3390/agriculture11080709

Received: 12 July 2021

Accepted: 16 July 2021

Published: 28 July 2021

Publisher's Note: MDPI stays neutral with regard to jurisdictional claims in published maps and institutional affiliations.

Copyright: (c) 2021 by the author Licensee MDPI, Basel, Switzerland. This article is an open access article distributed under the terms and conditions of the Creative Commons Attribution (CC BY) license (https:// creativecommons.org/licenses/by/ $4.0 /)$.
MDPI AG, St. Alban-Anlage 66, 4052 Basel, Switzerland; agriculture@mdpi.com

The Agriculture Editorial Office would like to make the following correction to the published paper [1].

In the original article, there was a mistake in Figure 3 as published. In the original article, an incorrect version of the Figure 3 has been used. The corrected Figure 3 appears below:

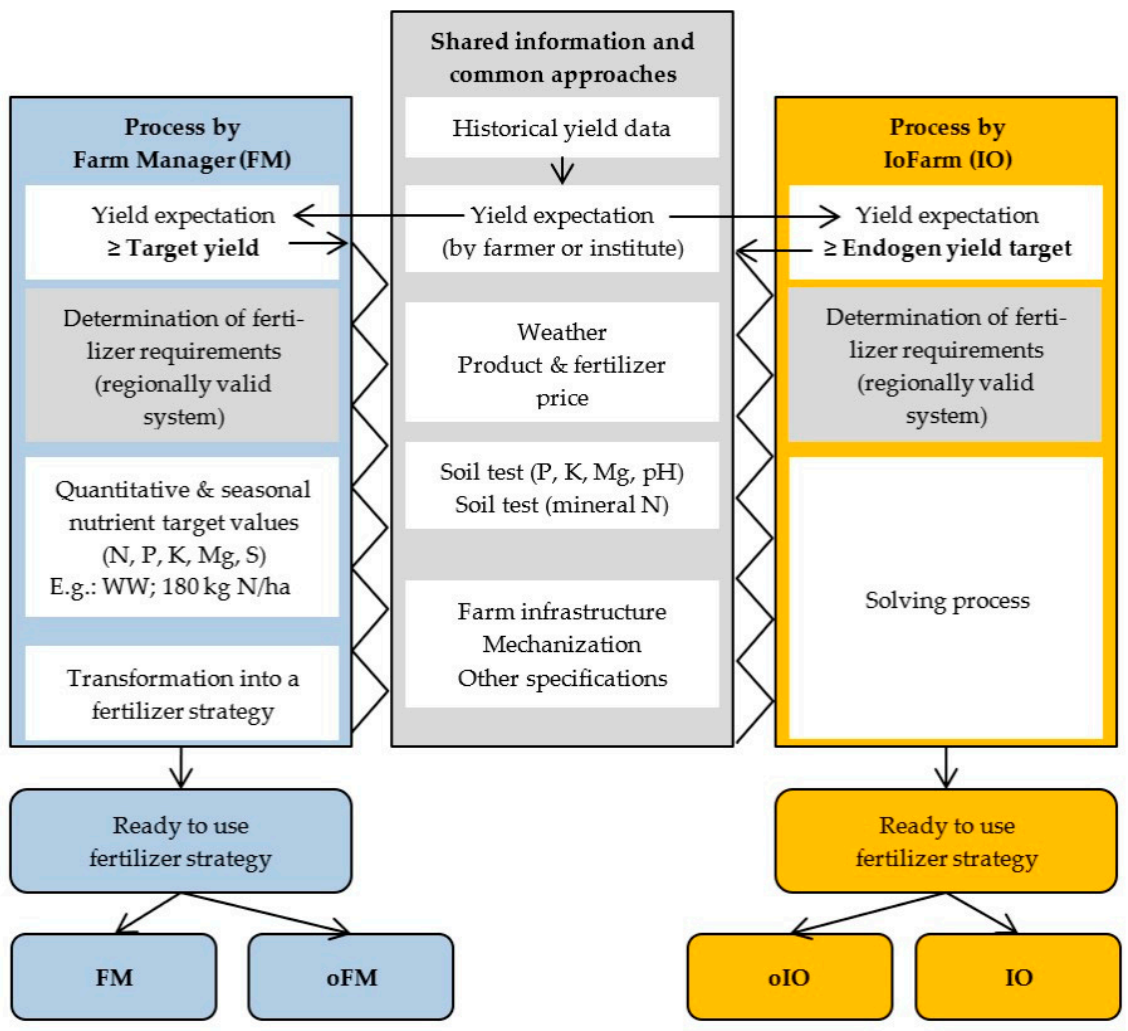

Figure 3. Similarities and differences in fertilizer strategy: Farm Manager and IoFarm.

We apologize for any inconvenience caused and state that the scientific conclusions are unaffected. The original article has been updated.

\section{Reference}

1. Tröster, M.F.; Sauer, J. IoFarm in field test: Does a cost-optimal choice of fertilization influence yield, protein content, and market performance in crop production? Agriculture 2021, 11, 571. [CrossRef] 